\title{
The Challenges of Initial Teacher Training
}

\author{
https://doi.org/10.3991/ijet.v16i18.24237 \\ Vânia Graça ${ }^{1(\bowtie)}$, Paula Quadros-Flores ${ }^{2}$, Altina Ramos ${ }^{1}$ \\ ${ }^{1}$ University of Minho, Portugal \\ ${ }^{2}$ Polytechnic of Porto, Portugal \\ vaniaadias14 egmail. com
}

\begin{abstract}
The initial training of teachers assumes great responsibility in the methodological renewal of teachers. This study aims to know the thinking of higher education students, future teachers, regarding their knowledge and attitudes towards the curricular integration of Information and Communication Technologies (ICT), as well as to identify inhibiting and propelling factors of the use of digital technology by future teachers. This study is part of the IFITIC Project, which aims to rethink educational practice with ICT in the initial training of future teachers in order to promote methodological renewal in Pre-school Education and the $1^{\text {st }}$ and $2^{\text {nd }}$ Cycles of Basic Education. We used the methodological design survey and for data collection we applied a questionnaire survey, with closed questions, to students of Basic Education and Vocational Master's degree from two public higher education institutions in the North of Portugal. The results point to the existence of inhibiting factors such as lack of resources in training centers, and propellants to ICT integration such as the availability of personal resources that can compensate for the lack of resources in school centers and ICT training by training schools. They also reveal a positive and open attitude on the part of students towards the educational use of ICT.
\end{abstract}

Keywords - initial teacher training, information and Communication Technologies (ICT), innovative methodologies, institutional challenges.

\section{$1 \quad$ Introduction}

The quality of initial teacher training represents a current challenge for teacher training institutions, since preparing quality teachers for $21^{\text {st }}$ century schools [4] implies the development of knowledge and skills in order to foster reflective, critical and creative teachers in a multicultural, technological and knowledge society [7]. In order to promote relevant technological and pedagogical knowledge in teaching a content, appropriating technologies, it is important that future teachers have technological resources, but their representations and knowledge in the construction of their teaching professionalism are equally important.

This study is part of the IFITIC Project "Innovate with ICT in Initial Teacher Education to Promote Methodological Renewal in Pre-school Education and in the $1^{\text {st }}$ and $2^{\text {nd }}$ Cycles of Basic Education" and aims to rethink educational practice with ICT in the 
initial training of future teachers in order to promote methodological renewal in Preschool Education and the $1^{\text {st }}$ and $2^{\text {nd }}$ Cycles of Basic Education.

In this sense, the aim of the study is to know the thinking of future teachers regarding their knowledge and attitudes towards the curricular integration of Information and Communication Technologies (ICT), as well as to identify inhibiting and propelling factors of the use of digital technology by future teachers.

This work is funded by CIEd - Research Centre on Education, Institute of Education, University of Minho, projects UIDB/01661/2020 and UIDP/01661/2020, through national funds of FCT/MCTES-PT.

\section{2 (Re) thinking about initial teacher training}

Reflecting on the initial training of teachers currently implies rethinking five major challenges: a) the new ways of learning and teaching; b) the cultural diversity of students; c) the integration of ICT in the classroom; and d) the development of skills, competencies, values and attitudes for the student of the $21^{\text {st }}$ century [5] and for the teacher of the digital age.

Learning and teaching today requires the planning of a set of learning opportunities, through strategic plans that integrate ICT in learning processes and significant practices [1], taking into account the interests and needs of students, their cultural diversity and the development of skills and values present in the Student Out of School Profile [13]. These competencies and values in the Student Profile are in line with the dimensions of global OECD competence for the $21^{\text {st }}$ century (Figure 1 ).

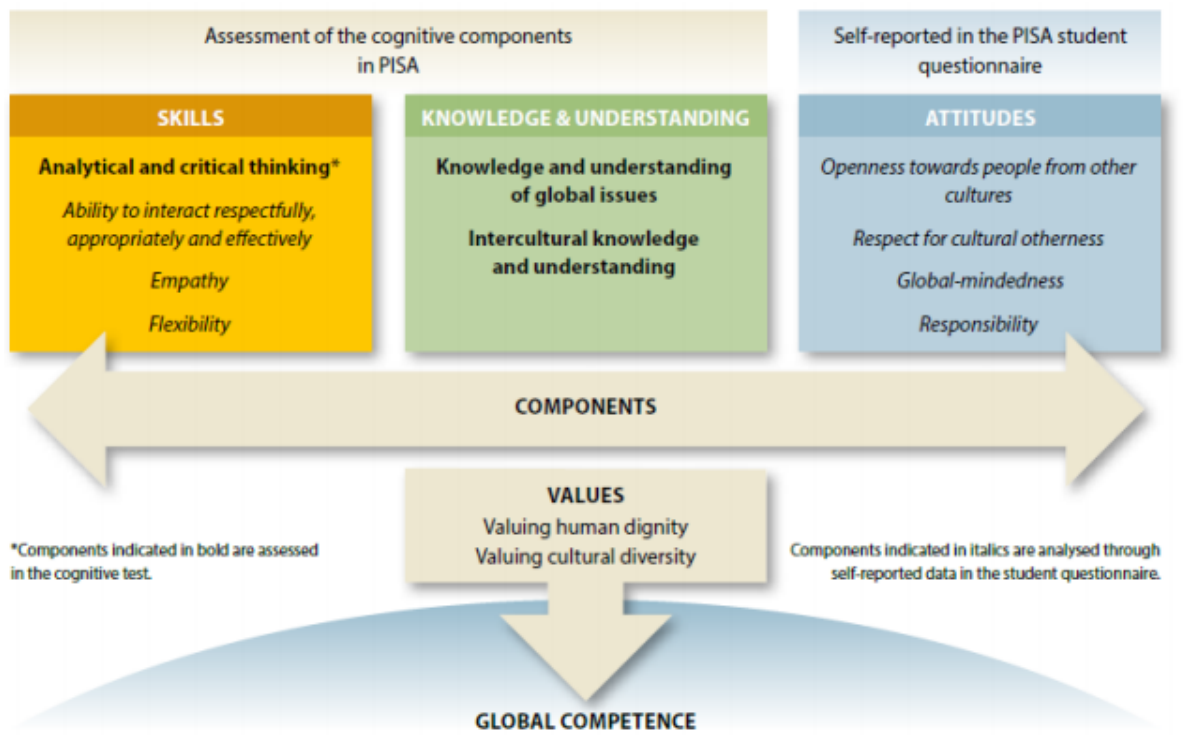

Fig. 1. Dimensions of global competence 
Global Competence requires the knowledge and understanding of global issues, as well as intercultural knowledge and understanding.

The skills dimension requires the ability to communicate appropriately and effectively with people from other cultures, to adjust thoughts, behaviors according to new contexts, because as [3] "the individual may have a wide range of knowledge, understanding and skills/skills, but lack the willingness to use them" (p. 60). The globally competent behavior and attitudes imply a posture of openness and respect for the individual, since the attitudes themselves revolve around values that are normally the reflection of the context in which the individual is inserted. It is the development of these skills that will make the citizen of tomorrow.

The present scheme, although directed towards the global competence of the student, is closely related to the global competence that is also expected to develop in the initial training of teachers, providing them with skills, knowledge and attitudes that meet the training requirements of the $21^{\text {st }}$ century.

It demands, therefore, that teachers in initial training transform their educational practices, mobilizing disciplinary, curricular, experiential and technological knowledge [15] into a socio-constructivist process [2] in which social interaction takes on importance in the transformation for the development of teaching professionalism.

On the other hand, we consider relevant the integration of principles that stimulate research-based learning (action-research, evidence-based teaching), the pedagogical use of ICT in the classroom, cooperative and collaborative learning, and the ability to build professional skills in the dialogue theory/practice important for the beginning of professional activity and new ways of teaching and learning.

In this sense, it is worth mentioning the study of [17] who investigated the feasibility and relevance of introducing the concept of flipped pedagogy based on hybrid learning to first-year university students, where the student is the center of the knowledge construction process. Implemented new teaching methods, to gather their perceptions of university studies and the difficulties encountered, as well as the opportunities that may arise to plan initial training courses that meet societal challenges. They concluded that students are motivated to embrace the pedagogical innovation implemented and therefore intend to continue the pedagogical model for students in the coming years.

Another study worth mentioning is the study of [16], which aimed to understand teachers' perception of the benefits of using online resources in their educational activities, namely the impact of using the "School Me" platform in the teaching and learning process. They found that teachers recognize the importance of using these resources, considering that they make the teaching process more attractive and increase the motivation for learning.

[18] analyzed the level of digital competence and computational thinking of 248 Spanish future teachers, exploring the relationships between both, and found that most students had a medium to high level of digital competence, emphasizing the multimedia and communicative dimensions, as opposed to the more technological aspects. On the other hand, there is a correlation between computational thinking and digital competence, especially with the communicative and technological areas.

In [8] vision, ICT empowers new teaching and learning methods, but they need a process of appropriation, not only by future teachers, but also by cooperating teachers 
and institutional supervisors. Therefore, the training and experience of the cooperative teacher and the institutional supervisor in guiding educational practice, stimulating activities that pedagogically integrate ICT in the dialectic process of teaching and learning [5] is fundamental in an internship situation.

There are several guidelines for developing the digital competence of educators in Europe. One of them is the DigCompEdu benchmark [19], which is oriented towards teacher training policies aiming at the digital proficiency of pro-teachers. It aims to support pedagogical practices that boost the active involvement of students in the teaching and learning process, mediated by digital technologies. The model of teacher progression presented in the framework, inspired by Bloom's taxonomy, through the cognitive phases of learning progression (Figure 2).

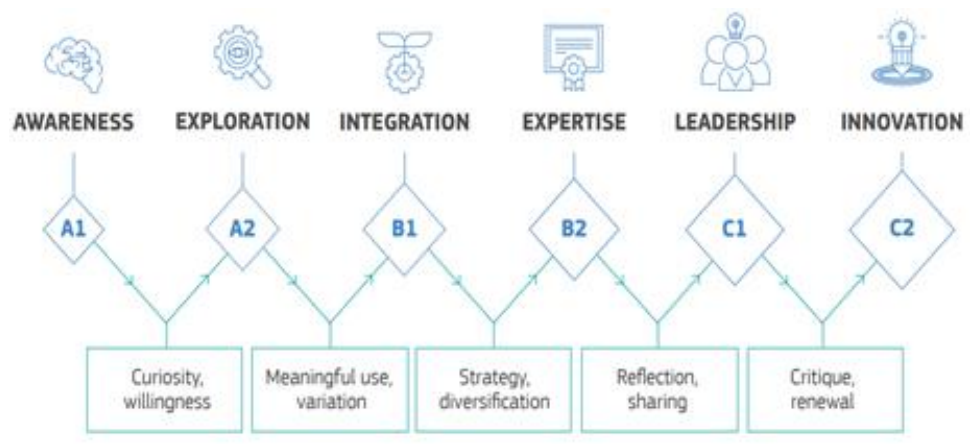

Fig. 2. DIGCOMPEDU progression model

The first two phases (A1) and (A2) require teachers to assimilate new information in order to develop their digital practices. The next two phases (B1) and (B2), envisages the teacher applying, deepening and reflecting on digital practices to reach the last two phases $(\mathrm{C} 1)$ and $(\mathrm{C} 2)$, which are the most complex of the process and which aim to transmit their knowledge, criticise their practices and develop new ones [19].

Thus, the ICT domain is not only about knowing its applicability, it is fundamental to develop technological and pedagogical capacities for an effective ICT integration. That is why the HEIs responsible for initial teacher training must provide training in scientific, didactic, pedagogical and technological aspects, thus following the social, economic and technological changes as well as the diversity of the teaching activity in the labor market [8], [14].

[11] refers to a "common house of formation and profession", uniting universities that train teachers, as a space for dialogue between university teachers dedicated to teacher training and teachers in the network. This "common house" allows the connection to the profession, through the articulation between the university, the society, the school and the teacher. According to the author, it is in this "house" that the relevant knowledge will be mobilized to train the teachers of the future and the place where the teaching profession is produced and valued.

Aware that the initial and continuous training of the teacher will be done in a dynamic process throughout life, we consider that the initial training was a remarkable 
moment in the development of basic skills of the future teacher, in the construction of a multifaceted teacher profile, in constant pedagogical and curricular innovation, within a context that is increasingly technological and digital [9].

\section{Methodology}

For the present study, a research/methodology survey, also known as a survey [6], was used to evaluate the thoughts, opinions and feelings of groups of individuals by requesting information from a significant group of people about the problem under study. The survey consisted of closed questions and intended to know and identify factors inhibiting and propelling the use of digital technology by future teachers in training centers and institutions.

\subsection{Sample}

There were 111 students in initial teacher training for the Basic Education Degree and a professional Master's Degree, i.e. students who were carrying out professional practices at two public higher education institutions in northern Portugal. The Bachelor's Degree in Basic Education does not have didactic curricular units, but it does have a curricular unit that addresses and works on the integration of ICT in education. The Master's program has curricular units directed to didactics, and the students carry out a professional internship in which one of the objectives is the use of ICT in their educational practices in school centers. Most of the students are female (97.3\%), and only $(2.7 \%)$ are male. The survey was applied at the end of the 2017/18 school year.

\section{$4 \quad$ Analysis and discussion of results}

Knowing the thinking of future teachers regarding their knowledge and attitudes towards the curricular integration of Information and Communication Technologies (ICT) in their practices and identifying factors inhibiting and propelling the use of digital technology by future teachers is currently a challenge for teacher training institutions.

Our purpose was to identify factors that drive or inhibit the integration of ICT in educational practices, namely what digital resources students make available in their training institution, in internship centers and on a personal level. The answers are reflected in the graph (Figure 3). 


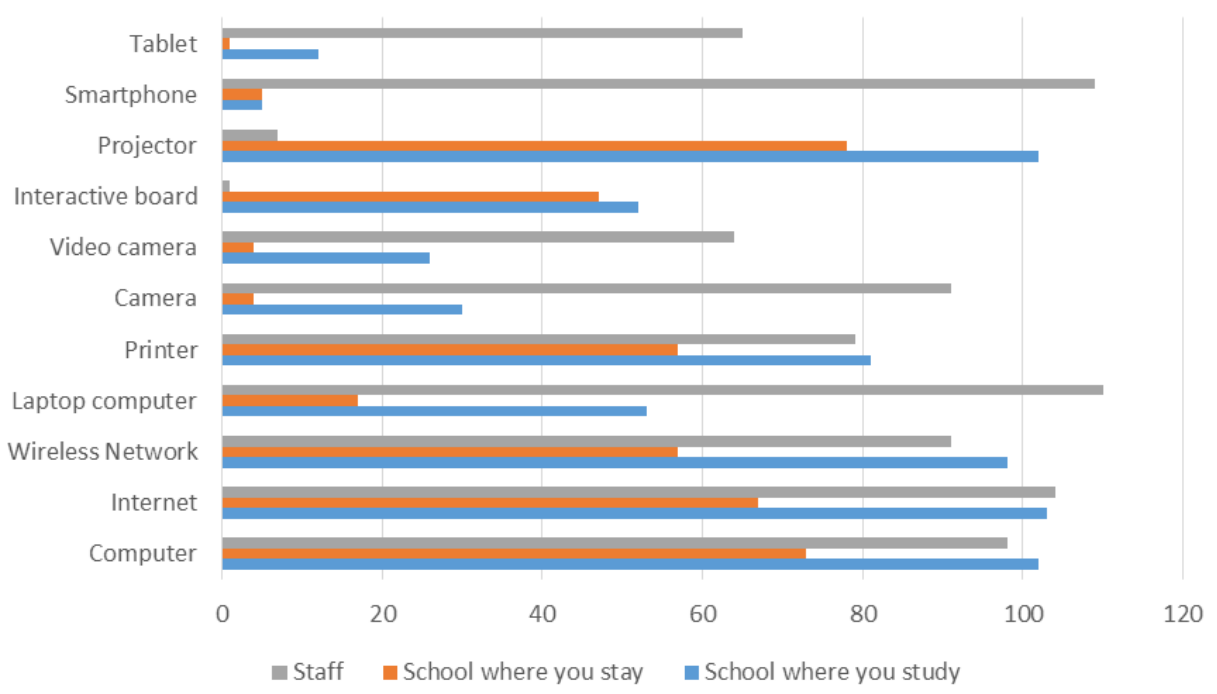

Fig. 3. Digital resources available in IES, internship centers and at the personal level

In general, figure 3 reveals that: internship centers are spaces poorly equipped with digital technologies and therefore offer fewer opportunities for ICT integration; the schools where they study respond to immediate needs with computers, Internet, Wireless Networks and projectors and that all students have personal resources (computer, smartphone and Internet), which favors the integration of ICT, compensating in some way (as figure 3 below seems to confirm), the failures in the school centers during the preparation of classes and the effective integration of digital technologies in their teaching practices with the objective of tracing significant learning paths for children [1]. Note that the computer $(66 \%)$, the projector $(70 \%)$, the internet $(60 \%)$ and the interactive board $(42 \%)$ are the most relevant resources in internship contexts. Since the Wireless Network exists in only $57 \%$ of the schools where they were educated, it will certainly be an inhibiting factor of collaborative practices for some of the students in training, or even individual research and production, as well as the lack of tablets (4\%) and the insufficient number of laptops (14\%), such as the video camera (7\%) and photographic (7\%). The school where they study reveals to have basic resources to build knowledge for the future teacher. Most students have personal resources that allow them to prepare for renewed educational practices, if the student has technical and pedagogical knowledge and creative abilities to do so. Future teachers do not have an interactive board or projector, but they are not expected to possess such materials.

In view of the above, namely the resources available in the internship centers, it was our purpose to realize what resources were most used in the educational practices in the internship centers by the future teachers (Fig. 4). The answers were introduced in a word cloud generator. In the cloud, the size of the word is directly proportional to the number of occurrences of that word in the text. 


\section{Tablet Classtools Internet \\ NLVN Mindmiester Projector Google \\ Tagxedo PowerPoint Plickers Youtube Webquest Excel Computer Geogebra Microsoft QRCodes Kahoot Voki word Wireless Network Cell phone

Fig. 4. Digital resources most used by students in internship centers

There are a high number of occurrences that point to the computer, the projector and the cell phone as the most used resources in the training centers. This result shows that students in training make more use of the resources that the school centers provide, but also their personal ones, or eventually requested in the school where they study.

It also reveals that the Internet, or Wireless Network, allows access to tools relevant to your educational practices, in addition to the traditional Windows (Word, Excel and PowerPoint). Thus, those who have access to the Internet, or Wireless Network, report using tools for creating avatars (Voki), related to gamification (Plickers, Kahoot, QRCodes, ClassDojo), video viewing (Youtube), ebook creation (Storyjumper), Slides presentation (Prezi), Web pages (and even safe guidance on the Internet through WebQuest), Excel, Word, PowerPoint, Blog, various platforms (Virtual School, NLVN, Geogebra), concept map (Mindmeister), creative writing (Tagxego).

The most referenced digital resources point to the possibility of integrating digital technologies in active methodologies [10] in the educational practices of students in initial education, with a view to an open and networked education that enables students to be creative and build their own knowledge at their own pace and learning from others.

We also wanted to know the frequency of use of these resources in School Centers to better understand what kind of digital resources students use most for the development of their educational practices in internship centers (Figure 5). 


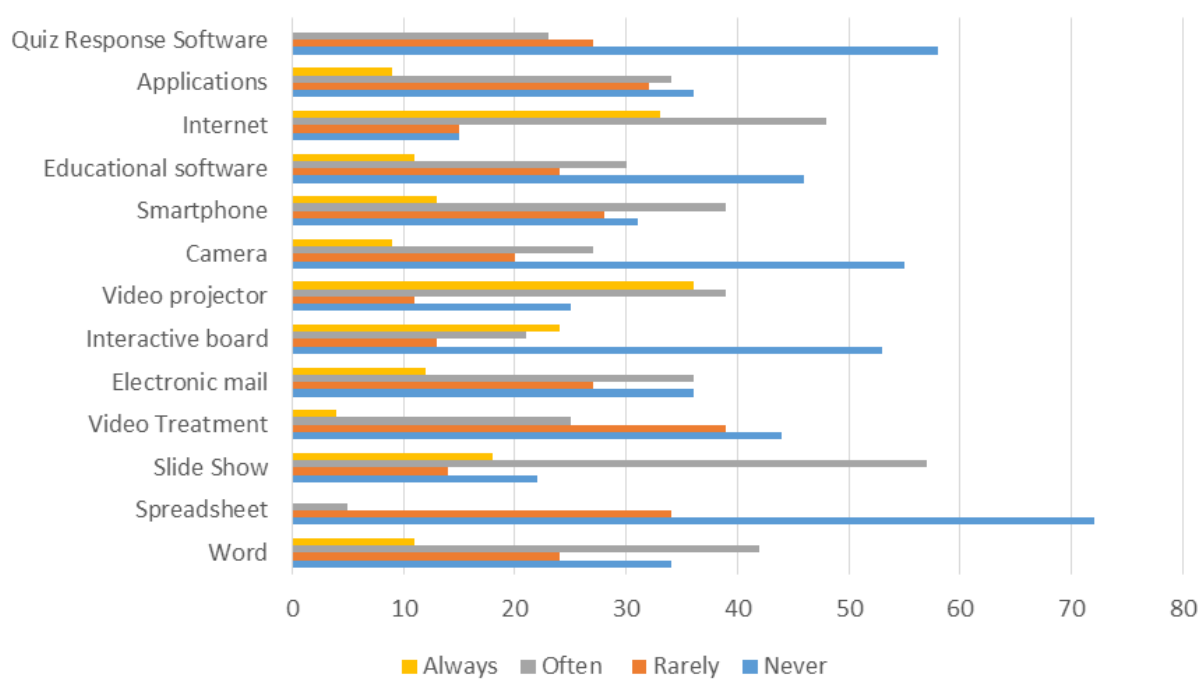

Fig. 5. Frequency of use of these resources in School Centers

It turns out that most, rarely or never, use the spreadsheet, frequently use slide show, quick response software, camera and interactive whiteboard. Note that, compared to the previous figure, there seems to be a paradox, however, although most do not use these tools, about $20 \%$ often use immediate response software (quiz) and always use (35\%), or often $(20 \%)$ the interactive whiteboard, $30 \%$ often use the camera and only $5 \%$ frequently use the spreadsheet. The fact that they do not always use the same resource shows that students understand that they should be varied and selected only if they add value to the class, improving the learning process and motivation of children. If we consider "always" and "often", most students use internet, interactive whiteboard, video projector and smartphone.

Finally, it was our goal to perceive the level of agreement, through a Likert type scale, regarding some statements regarding the use of ICT, in order to better understand some attitudes on the part of students regarding the pedagogical use of ICT, as well as the development of learning opportunities in their training contexts (Figure 6).

It turns out that $50 \%$ would like to know more about ICT. Most of them say that ICT helps them to improve their classes (59\%), that they feel motivated to use it and that they motivate students $(61 \%)$, which means that they are aware of its beneficial effects, assuming a positive attitude towards its integration into educational practices. However, only $44 \%$ consider that ICTs help us build their knowledge; $38 \%$ believe that they handle information better because they use ICTs and that they facilitate their routines, which leads us to believe that most students have already understood that their knowledge is built on the interception of theory with practice, that it depends on their personal and professional skills, and that ICTs are resources that facilitate access to information. It should be noted that most students do not consider their ICT mastery better than they do (68\%), which may indicate that they feel they have acquired the knowledge and skills to feel comfortable in front of a class of children. Confirming this, 
we find that they disagree that ICT in the classroom requires skills that they have not yet developed (49\%), as well as disagree with the fact that computers frighten them. Finally, it should be noted that students consider that the training center has minimum conditions for using digital resources (35\%), which leads us to an attempt to develop learning opportunities through strategic plans that integrate ICT in learning processes and significant practices [1] by training institutions and training centers.

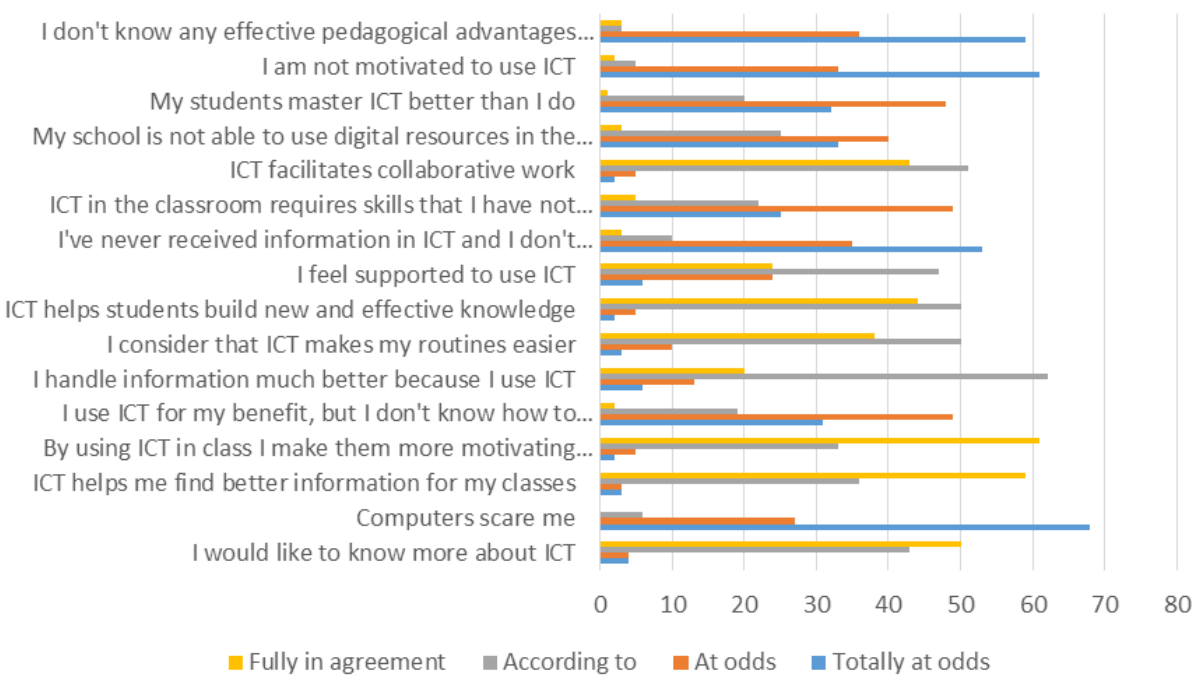

Fig. 6. Students' opinions on the use of ICT

\section{Conclusion}

Considering the issues of the study, the results show that internship centers are spaces that inhibit practices with ICT, since they do not have diverse resources that promote diverse practices with ICT, but that personal resources, and eventually those of the school where they study, can compensate for this limitation. In this sense, it seems to us that there is a need to include the "available technological equipment" dimension in the selection of internship centers, making it a facilitator of new learning environments, because it is in practice and in confrontation with reality that professional teaching knowledge is acquired and developed, including the use of digital technologies. The results also show that students already apply digital resources in educational practices, although they do not do so very often, which opens up the possibility of research in this field, since they assume a positive and open attitude towards the integration of ICT because they are aware. 


\section{Acknowledgment}

This work is funded by CIEd - Research Centre on Education, Institute of Education, University of Minho, projects UIDB/01661/2020 and UIDP/01661/2020, through national funds of FCT/MCTES-PT.

\section{$7 \quad$ References}

[1] M. Almeida \& J. Valente, Tecnologias e currículo: trajetórias convergente ou divergentes?, São Paulo: Paulus, 2011

[2] M. Azenha, Construtivismo: de Piaget a Emília Ferreiro, Editora Ática, 2010.

[3] E. Faria, I. Rodrigues, R. Perdigão and S. Ferreira, Perfil do aluno - competências para o século XXI, Lisboa: Conselho Nacional de Educação, 2017.

[4] M. A. Flores, "Formação de professores: questões críticas e desafios a considerar", in Conselho Nacional de Educação, Atas do Seminário Formação Inicial de Professores (CNE), 192-222, 2015. https://doi.org/10.47749/t/unicamp.2017.980934

[5] C. Galvão, J. Ponte, and M. Jonis, "Os Professores e a sua Formação Inicial”, in Práticas de Formação Inicial de Professores: Participantes e Dinâmicas, 25-46. Lisboa: Instituto de Educação, Universidade de Lisboa, 2018. http://hdl.handle.net/10451/32762, https://doi.org /10.24140/issn.1645-7250.rle45.15

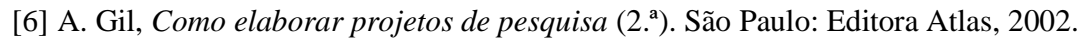

[7] A. Hargreaves, "Mudança educacional inclusiva e exclusiva: respostas emocionais de professores e implicações para a liderança", Liderança Escolar e Gestão, vol. 24, p. 287309, 2004. https://doi.org/10.1080/1363243042000266936

[8] W. Leite and C. Ribeiro, "A inclusão das TICs na educação brasileira: problemas e desafios”, Revista Internacional de Investigación En Educación, vol. 5, no 10, p. 173-187, 2012. https://www.redalyc.org/articulo.oa?id=281024896010

[9] C. Mesquita, M. Pires, and R. Lopes, Contributos para uma formação na docência de (mais) qualidade. Bragança: Instituto Politécnico de Bragança, 2016. https://doi.org/10.24927/ $\underline{\text { rce2016.027 }}$

[10] J. Moran, "Mudando a educação com metodologias ativas". Coleção Mídias Contemporâneas, Convergências Midiáticas, Educação e Cidadania: Aproximações Jovens, vol. 2, 2015.

[11] A. Nóvoa, "Os Professores e a sua Formação num Tempo de Metamorfose da Escola", Educação \& Realidade, vol. 44, no. 3, p. e84910-e84915, 2019. https://doi.org/10.1590/ $\underline{2175-623684910}$

[12] OECD. Global competency for an inclusive world, 2016.

[13] G. Oliveira-Martins, C. Gomes, J. Brocardo, J. Pedroso, L. Silva, M. Encarnação, M. Horta, M. Calçada, R. Nery and S. Rodrigues, Relatório Técnico- Perfil dos alunos à Saída da Escolaridade Obrigatória. Lisboa: Ministério da Educação/Direção-Geral da Educação, 2017. https://doi.org/10.18316/recc.v24i1.5603

[14] J. Ponte, "Tecnologias de informação e comunicação na formação de professores: Que desafios?”, Revista Iberoamericana de Educación, vol. 24, p. 63-90, 2000. https://doi.org/ $10.35362 /$ rie240997

[15] M. Tardif, Saberes docentes e formação profissional. Rio de Janeiro: Editora Vozes, 2002. 
[16] K. Shatri, K. Buza, F. Bunjaku, “Teachers' Perception on the Benefits of Using Online Resources", International Journal of Emerging Technologies in Learning (iJET), vol. 16, no. 11, p. 289- 307, 2021. https://doi.org/10.3991/ijet.v16i11.21407

[17] L. Ouchaouka, Z. Laouina, M. Moussetad, M. Talbi, N. Elamrani, M. ElKouali, “The Effectiveness of a Learner-Centered Pedagogical Approach with Flipped Pedagogy and Digital Learning Environment in Higher Education Feedback on a Cell Biology Course", International Journal of Emerging Technologies in Learning (iJET), vol. 16, no. 11, p. 4-15, 2021. https://doi.org/10.3991/ijet.v16i12.19125

[18] F. M. Esteve-Mon, M. Llopis, J. Adell-Segura, "Digital Competence and Computational Thinking of Student Teachers", International Journal of Emerging Technologies in Learning (iJET), vol. 16, no. 11, p. 29-41, 2020. https://doi.org/10.3991/ijet.v15i02.11588

[19] C. Redecker. European Framework for the Digital competence of Educators. Yves Punie, 2017.

\section{Authors}

Vânia Graça is a Masters in Teaching in the $1^{\text {st }}$ Cycle of Basic Education and Portuguese and History and Geography of Portugal in the $2^{\text {nd }}$ Cycle of Basic Education from the Higher School of Education of Porto (Portugal). Is a degree in Basic Education from the Institute of Education of the University of Minho (Portugal). Is currently doing her $\mathrm{PhD}$ in Education Sciences, specialising in Educational Technology at the University of Minho, developing a project funded by the Foundation for Science and Technology (FCT). Is a researcher and collaborator at the Centre for Research in Education (CIEd) at the University of Minho and at the Centre for Research in Innovation of the Polytechnic Institute of Porto (InED). Has some communications and publications in the area of Education. Her areas of study are: Educational Technology; Active Methodologies; History Education; Teaching and learning of History; Historical Consciousness; Historical Thinking; Basic Education; Teacher Training.

Paula Quadros-Flores is Adjunct professor at the Polytechnic of Porto, School of Education, being Coordinator of the Technical Scientific Unit of Supervised Pedagogical Practice and responsible for the curricular unit of Initiation to Pedagogical Practice III (Degree in Basic Education). Is Doctor in Education Sciences in the speciality of Educational Technology, Master in Management and Educational Planning is an integrated member of InED (Centre for Research and Innovation in Education) and collaborates with the Philosophy Research Centre of the Faculty of Arts of the University of Porto. She works in the areas of ICT in Education, Teacher Training and Pedagogical Supervision and Professional Teaching Identity of teachers of the $1^{\text {st }} \mathrm{CEB}$, and is the author of national and international scientific articles, principal investigator of the project IFITIC.

Altina Ramos is teacher and researcher at the Institute of Education - University of Minho, where she teaches Master's and Doctorate courses in the area of ICT in Education, Methodology of Research in ICT and Supervision of Pedagogical Practice. Is doctor in Child Studies - Information and Communication Technologies Communication Technologies from the University of Minho with the thesis Children, Technologies and Learning - contribution contribution to a substantive theory She has a post-doctoral in 
Education: Curriculum from the Pontifical Catholic University of São Paulo - Brazil. Her current research interests are: technologies and learning processes; curricular integration of ICT; research with children; grounded theory and qualitative analysis of data analysis with NVivo support. She has published several papers in these areas.

Article submitted 2021-05-24. Resubmitted 2021-07-06. Final acceptance 2021-07-07. Final version published as submitted by the authors. 